\title{
アミノ酸および脂肪酸を原料とする新しい 界面活性剤について
}

\author{
吉田良之助*・竹原 将 博*
}

\author{
New Surfactants Derived from Amino Acids and Fatty Acids.
}

\section{I.は浔めにに}

化学工業の進歩は多くの化学製品を生み出し, われわ れの日常生活を豊かにしている。しかし，その生産の拡 大に伴って廃畗物の量が増大し, 適切な処理が要求され るようになった。さらに, 化学物質による環境の污染と 生体への悪影響が問題となり, その解決を迫られてい る。

界面活性剤に関しても，その主な用途である洗浄剤の 分野で，人体に対する安全性はもとより，環境保全への 影響に対して関心が高まっている1)。とくに, 野菜, 食 器用液体洗剂には, 主に直鎖アルキルベンゼンスルホン 酸ナトリウム (LAS) が用いられているが，洗剤による 主婦の手荒れの問題が発端となり，手荒れの少ない脂肪 酸系の界面活性剤を主剤とする洗 剂が登場した ${ }^{2}$ 。この ような情勢下においては, より毒性が低く, より生分解 性の高、界面活性剤が要望される。

アミノ酸および脂肪酸は生体の構成成分であり, 生分 解性にすぐれ，かつ生体に対し，ほとんど悪影響のない 物質である。したがって，これらの物質を原料にする と, 安全性が高くかつ生分解性のよい界面活性剂を合成 できると考えられる。アミノ酸から界面活性剤を得るに は，アミノ基またはカルボキシル基の反応性を利用し て，疎水基を導入する必要がある。すなわち，アミノ基 と長鎖脂肪酸を縮合させた $N$-アシルアミノ酸*1), カル ボキシル基と高級アルコールとのエステル，または高級

\footnotetext{
* 味の素株式会社中央研究所

* Central Research Laboratories of Ajinomoto Co., Inc.
}

Ryonosuke YoshidA* and Masahiro TAKeHARA*

アミンとのアミド，およびアミノ基の $N$-アルキル化物 などがある。中性または酸性アミノ酸から得られた $N$ アシルアミノ酸塩はアニオン界面活性剤であり，塩基性 アミノ酸のモノアシル化物は両性界面活性剤となり得 る。また, アミノ酸エステルはカチオン界面活性剤, $N$ アルキルアミノ酸は両性界面活性鼡となる。ここでは, 主にアミノ酸および脂肪酸から誘導された $N$-アシルア ミノ酸塩の合成法, 性質および用途について述べ, 同時 にアミノ酸から誘導された界面活性片についても簡単に 触れたい。

\section{II. $N$-アシルアミノ酸塩}

1. N-アシルアミノ酸塩 1909 年, Bondi は組織 の壊死の際にみられる細胞の脂肪変性の原因として, ア シルアミノ酸が酵素によって分解され脂肪酸とアミノ酸 になるためと考え，N-ラウロイルーグリシンおよびーア ラニンを合成したが3)，N-アシルアミノ酸の研究はこ のときから始まった。この研究は進展をみなかったが， その後, Abderhalden ら ${ }^{4)}$, Izar $^{5)}$, Karrer ら ${ }^{6) か ゙ こ れ に ~}$ 続いた。界面活性剤としての研究は初期において, Hentrich らが $N$-アシルザルコシン塩, $N$-アシルグリシン 塩および $N$-アシルアスパラギン酸塩を洗浄㓮, シャン プー，ハミガキに用い得ることを示しだ,8)。また Staudinger らは $N$-アシルザルコシン塩の溶解性, 粘度を 測定した ${ }^{9)}$ 。1950 年, Naudet は $N$-アシルセリン, $N$ アシルロイシンなどを合成し，そのナトリウム塩水溶液 の表面張力および界面張力を測定し，良好な界面活性能 を有することを認めた ${ }^{10)}$ 。局は多くの $N$-アシルアミノ 酸を合成し，それらの界面活性能を測定し，アミノ酸部 分と界面活性およびアシル基の炭素数と界面活性の関係

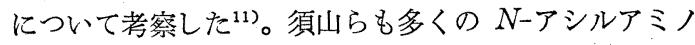


酸を合成している ${ }^{12)}$ 。近年, Heitmann は $N$-アシルーシ スティン，一セリン，およびーグリシンのナトリウム塩の 臨界ミセル濃度 $(\mathrm{cmc})$ を測定し, タンパク質中におけ るシスティン残基の異なった反応性を推定している13, 14)。

従来, 多くのアシルアミノ酸の中で $N$-ラウロイルザ ルコシンナトリウムのほか二三のものがはみがき, シャ ンプーなどの添加剤として用いられていたが, 最近 $N$ アシルーレーグルタミン酸塩の研究が行なわれ, 実用化さ れた ${ }^{15)}$ 。

2. $N$-アシルアミノ酸の合成 $N$-アシルアミノ酸 はアミノ酸と脂肪酸八ライド, 脂肪酸無水物または脂肪 酸および脱水剤ふら合成される。通常, アミノ酸の水溶 液にアルカリの存在下, 脂肪酸クロリドを反応させるい わゆる Schotten-Baumann 法が用いられる ${ }^{3)}$ 。

$$
\begin{aligned}
& \mathrm{R}^{\prime}-\mathrm{CH}-\mathrm{COONa}+\mathrm{RCOCl} \longrightarrow \mathrm{R}^{\prime}-\mathrm{CH}-\mathrm{COONa} \\
& \mathrm{NH}_{2} \quad \mathrm{NH}-\mathrm{COR}
\end{aligned}
$$

本法はいわゆる中性アミノ酸（モノアミノモノカルボン 酸) のアシル化には操作が簡単で, 収率もよいのでしば しば用いられるが，水酸基またはチオール基をむつアミ ノ酸の場合, それらの基も同時にアシル化されることが ある。セリン, トレオニンの場合, アルカリ性では $O$ アシル化されにくいが, チロシンは $N, O$-ジアシル化さ れる ${ }^{12)}$ 。また，リジンのような塩基性アミノ酸はジアシ ル化されるので, モノアシル化物を得るには一方のアミ ノ基を保護する必要がある。

酸性アミノ酸のグルタミン酸のアシル化は Kester に より初めて報告されたが ${ }^{16)}$,この方法では収率が低く ${ }^{17)}$, 副生する脂肪酸の分離が困難であった。そこでグルタミ ン酸をジエステル化した後, アシル化し, これをケン化 して $N$-アシルグルタミン酸を得る迂回法がとられてい $\hbar^{18,19 \%}$ 。

$$
\begin{aligned}
& \mathrm{HOOC}-\mathrm{CH}_{2}-\mathrm{CH}_{2}-\mathrm{CH}-\mathrm{COOH} \\
& \mathrm{NH}_{2} \\
& \stackrel{\mathrm{CH}_{3} \mathrm{OH}-\mathrm{HCl}}{\longrightarrow} \mathrm{CH}_{3} \mathrm{OOC}-\mathrm{CH}_{2}-\mathrm{CH}_{2}-\mathrm{CH}-\mathrm{COOCH}_{3} \\
& \stackrel{1}{\mathrm{NH}_{2}} \mathrm{HCl} \\
& \stackrel{\mathrm{RCOCl},\left(\mathrm{C}_{2} \mathrm{H}_{5}\right)_{3} \mathrm{~N}}{\longrightarrow} \mathrm{CH}_{3} \mathrm{OOC}-\mathrm{CH}_{2}-\mathrm{CH}_{2}-\mathrm{CH}-\mathrm{COOCH}_{3} \\
& \text { NH-COR } \\
& \begin{array}{r}
\underset{\mathrm{N}) \mathrm{NaOH}}{2} \mathrm{HCl} \\
\mathrm{HOOC}-\mathrm{CH}_{2}-\mathrm{CH}_{2}-\underset{1}{\mathrm{CH}} \mathrm{C}-\mathrm{COOH}
\end{array}
\end{aligned}
$$

最近, 著者らはグルタミン酸に脂肪酸クロリドを反応 させる際, 溶媒を水と水に可溶な溶媒（アセトン, ジオ キサンなど）の混合溶媒を用い，反応時の $\mathrm{pH}$ を制御す ることにより, 高收率で, 高純度の $N$-アシルグルタミ
ン酸が得られることを見出し20)，その工業的製造を可能 にした。

アシル化剤を脂肪酸クロリドに代えて脂肪酸無水物を 用いる方法もあるが, 当量の脂肪酸が副生するので, 生 成物との分離が必要となる。また, 脂肪酸とクロロ炭酸 アルキルをトリエチルアミンの存在下に反応させ, 混合 酸無水物を合成し，これをアシル化剂として用いる方法 11,12,21 24) もあるが，工業的製法としては不適当である。

$$
\begin{aligned}
& \mathrm{R}-\mathrm{COOH}+\mathrm{C}_{2} \mathrm{H}_{5} \mathrm{OCOCl} \stackrel{\left(\mathrm{C}_{2} \mathrm{H}_{5}\right)_{3} \mathrm{~N}}{\longrightarrow} \underset{\mathrm{C}_{2} \mathrm{H}_{5} \mathrm{OCO}^{\prime}}{\mathrm{R}-\mathrm{CO}} \\
& \mathrm{R}^{\prime}-\mathrm{CH}-\mathrm{COOH} \\
& \stackrel{\mathrm{NH}_{2}}{\longrightarrow} \mathrm{R}^{\prime}-\mathrm{CH}-\mathrm{COOH} \\
& \text { NH-COR }
\end{aligned}
$$

アミノ酸と脂肪酸を加熱脱水すると $N$-アシルアミノ 酸が得られる ${ }^{25)}$ 。この方法は中性アミノ酸のアシル化に は好都合であるが，グルタミン酸の場合にはアシル化よ りピロリドン化の方が進み易く, N-アシルグルタミン 酸を得るのは困難である。また, リジンのような塩基性 アミノ酸の脂肪酸塩を加熱し, 脱 水すると, $N^{\varepsilon}$ アアシル リジンが優先的に生成する。この方法によれば，保護基 を用いることなく $N^{\varepsilon}$-アシルリジンが合成できるので, 好都合である ${ }^{26) 。 ~}$

$$
\begin{aligned}
& \mathrm{R}-\mathrm{COOH}+\mathrm{R}^{\prime}-\mathrm{CH}-\mathrm{COOH} \stackrel{\Delta}{\longrightarrow} \mathrm{R}^{\prime}-\mathrm{CH}-\mathrm{COOH} \\
& \mathrm{NH}_{2} \quad \mathrm{NH}-\mathrm{COR} \\
& \text { R-COOH- } \mathrm{NH}_{2}-\mathrm{CH}_{2}-\mathrm{CH}_{2}-\mathrm{CH}_{2}-\mathrm{CH}_{2}-\mathrm{CH}-\mathrm{COOH} \\
& \mathrm{NH}_{2} \\
& \stackrel{\Delta}{\longrightarrow} \mathrm{RCO}-\mathrm{NH}-\mathrm{CH}_{2}-\mathrm{CH}_{2}-\mathrm{CH}_{2}-\mathrm{CH}_{2}-\mathrm{CH}-\mathrm{COOH} \\
& \mathrm{NH}_{2}
\end{aligned}
$$

そのほか, Schotten-Baumann 法の改良 ${ }^{27,28)}$, 長鎖ア ルキルアミジンまたはイミノエーテルとアミノ酸との反 応 $^{29)}$, 脂肪酸とアミノ酸エステルをジシクロヘキシルカ

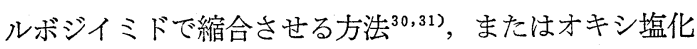
リンとトリエチルアミンとで縮合させる方法 ${ }^{22}$ などがあ る。

さらに，ストレッカー法によるアミノ酸合成の中間体

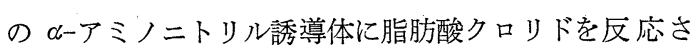
せ， $\propto$-アシルアミドニトリル誘導体を合成し，これを 加水分解して, $N$-アシルアミノ酸に導く方法 ${ }^{20,33)}$, ま たは, 高級脂肪酸アミドとアルデヒドをコバルトカルボ ニルの存在下, 一酸化炭素と反応させることにより， 一挙に $N$-アシルアミノ酸を合成する方法むある ${ }^{34,35) 。}$

$$
\begin{aligned}
& \mathrm{R}^{\prime}-\mathrm{CHO}+\mathrm{NH}_{4} \mathrm{CN} \longrightarrow \mathrm{R}^{\prime}-\mathrm{CH}-\mathrm{CN} \\
& \mathrm{NH}_{2} \\
& \stackrel{\mathrm{RCOCl}, \mathrm{NaOH}}{\longrightarrow} \mathrm{R}^{\prime}-\mathrm{CH}-\mathrm{CN} \\
& \text { NH-COR }
\end{aligned}
$$




\section{$\underset{\text { 1) } \mathrm{NaOH}}{\stackrel{\mathrm{HCl}}{\longrightarrow}} \mathrm{R}^{\prime}-\mathrm{CH}-\mathrm{COOH}$}

$\mathrm{R}^{\prime}-\mathrm{CHO}+\mathrm{R}-\mathrm{CONH}_{2}+\mathrm{CO} \stackrel{\mathrm{Co}_{2}(\mathrm{CO})_{8}}{\longrightarrow} \mathrm{R}^{\prime}-\underset{1}{\mathrm{C} H}-\mathrm{COOH}$ NHCOR

これらのほかに, アシル化剤として脂肪酸イソプロペ ニルエステルが有用という報告がある ${ }^{36)}$ 。脂肪酸イソプ ロペニルエステルは次式のようなエステル交換反応によ り得られるが，実用的な合成法としては，メチルアセチ レンと脂肪酸を亜鉛を触媒として加圧下に反応させる。

$$
\begin{aligned}
& \mathrm{CH}_{3} \mathrm{COO}-\mathrm{C}_{\mathrm{CCH}_{3}}^{2 \mathrm{CH}_{2}}+\mathrm{R}-\mathrm{COOH}
\end{aligned}
$$

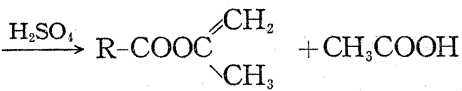

この反応は連続化が可能で, 精製は流下薄膜式蒸留に

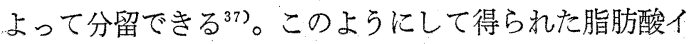

$$
\mathrm{R}-\mathrm{COOH}+\mathrm{CH}_{3}-\mathrm{C} \equiv \mathrm{CH} \underset{150 \mathrm{C}}{\stackrel{\mathrm{Zn}}{500 \mathrm{ps}}} \mathrm{R}-\mathrm{COOC}^{\stackrel{\mathrm{CH}_{2}}{\mathrm{CH}_{3}}}
$$

ソプロペニルは純度が高い。通常の脂肪酸クロリドに は，製造工程からリンまたはイオウが不純物として混入 する可能性があり，かつ，アシル化反応に際して食塩が 副生する欠点がある。これに対し，イソプロペニルエス テルを用いると，アシル化によりアセトンが副生するの みで反応後の処理も容易と考えられる。

脂肪酸イソプロペニルエステルのアシル化剤としての 適用範囲にアルコール，アミンなどとの反応が報告され ており，N-メチルタウリン，イセチオン酸のアシル化 の例がみられる ${ }^{38)}$ 。

3. $N$-アシルアミノ酸塩の界面活性能 中性アミ ノ酸または酸性アミノ酸のアシル化物の水溶性塩はアニ オン界面活性剤となる。N-アシルアミノ酸塩とそのア シル基の炭素数と同じ長さの脂肪酸塩を比較したとき, $N$-アシルアミノ酸塩は水溶性, 耐硬水性が向上し, 水 溶液の $\mathrm{pH}$ は低下寸る。

局は $N$-アシルバリン塩を中心として，中性アミノ酸 のアシル化物の界面活性能を測定した ${ }^{11)}$ 。その結果, $N$-アシル-Lーバリンナトリウムの $\mathrm{cmc}$ の対数 $(\log \mathrm{cm}$ c）とアシル基の炭素数 $(N)$ との閒に直線 関係を認め た。また，アミノ酸部分と界面活性能との関係は，二三 の例外を除いてアシル基が同じであればおよそ同程度の 界面活性能をむっていると報告した。また，Heitmann は各種 $N$-アシルアミノ酸の $\mathrm{cmc}$ を測定し, $N$-アシ ルシスティンが若干異なった挙動を示すことを認めた ${ }^{13}$, 114)。N-アシルザルコシンナトリウムは水溶性が高いこ とが古くから知られているが，大木らはその界面活性能
を詳細沉測定した ${ }^{399}$ 。

著者らは, $N$-アシルグルタミン酸塩の光 学活性体お よびラセミ体について，界面活性能を詳細に測定した。

表 1 N-アシル-L-グルタミン酸塩の界面活性能

\begin{tabular}{|c|c|c|c|c|c|c|c|}
\hline \multirow{2}{*}{ 試 料') } & \multicolumn{2}{|c|}{ 溶解性 ${ }^{2)}$} & \multirow{2}{*}{$\begin{array}{c}\mathrm{cmc}^{3)} \\
\mathrm{mmol} / \mathrm{l}\end{array}$} & \multirow{2}{*}{$\begin{array}{c}\text { 起泡力6) } \\
\text { 分值 } \\
\text { mm }\end{array}$} & \multirow{2}{*}{$\begin{array}{c}\text { 表面張 } \\
\text { dyne/cm }\end{array}$} & \multirow{2}{*}{\begin{tabular}{|c} 
浸透力 \\
sec
\end{tabular}} & \multirow{2}{*}{$\begin{array}{c}\text { 耐硬水性 } \\
\mathrm{CaCO} \\
\text { として } \\
\mathrm{ppm} \\
\end{array}$} \\
\hline & 室温 & $40^{\circ} \mathrm{C}$ & & & & & \\
\hline LGS & G & $\mathrm{S}$ & 10.6 & 219 & 26.4 & 6.5 & 414 \\
\hline MGS & S P & S P & $7.2^{4)}$ & 212 & & & \\
\hline PGS & S P & S P & $5 \sim 6^{4)}$ & 176 & 35.9 & & \\
\hline S GS & S P & S P & & 139 & 39.6 & & \\
\hline OGS & $\mathrm{S}$ & S & $3.3^{5)}$ & 169 & 29.6 & 12.4 & 244 \\
\hline LGT & G & $\mathrm{S}$ & $5.4^{5)}$ & 201 & 25.6 & 5.0 & 531 \\
\hline$M G T$ & $\mathrm{~S} \mathrm{H}$ & $\mathrm{SH}$ & $5.0^{5)}$ & 228 & 29.5 & 9.4 & \\
\hline PGT & S P & S P & $4^{4>5)}$ & 223 & 31.8 & & \\
\hline $\mathrm{SGT}$ & S P & S P & $3^{4) 5)}$ & 180 & 34.5 & & \\
\hline OGT & $\mathrm{S}$ & $\mathrm{S}$ & & 162 & 30.2 & 8.8 & 244 \\
\hline $\mathrm{MGS}_{2}$ & $\mathrm{~S}$ & $\mathrm{~S}$ & 21 & 10 & 50.0 & 26.1 & 32 \\
\hline $\mathrm{PGS}_{2}$ & $\mathrm{~S}$ & S & 9.8 & 42 & 51.2 & 35.4 & 310 \\
\hline $\mathrm{SGS}_{2}$ & $\mathrm{~S}$ & $S$ & 4.5 & 149 & 48.3 & 162.2 & 439 \\
\hline $\mathrm{OGS}_{2}$ & $\mathrm{~S}$ & $\mathrm{~S}$ & $\begin{array}{r}5.2 \sim \\
5.9^{5)}\end{array}$ & 142 & 46.8 & 25.7 & 323 \\
\hline SLS & $\mathrm{S}$ & S & & 186 & 32.0 & 7.4 & 2000 \\
\hline SLSa & $\mathrm{S}$ & $\mathrm{S}$ & & 141 & 40.8 & 6.7 & 340 \\
\hline
\end{tabular}
$\left(10 \mathrm{mmol} / l, 40^{\circ} \mathrm{C}\right)$

1） $N$-アンルーLーグルタミン酸篮の略号 左端はアンル基（L：ラウロイル， $\mathrm{M}:$ :リストイル, $\mathrm{P}:$ パルミトイル, $\mathrm{S}:$ ステアロイル, $\mathrm{O}:$ オレオイ ル), 右端は塩の種類 ( $\mathrm{S}:$ ナトリウム $\mathrm{S}_{2}$ : ジナトリウム, $\mathrm{T}$ : トリエ夕 ノールアミン）女示す。例, LGS : $N$-ラウロイル-Lーグルタミン 酸 モノ ナトリウム, $\mathrm{MGS}_{2} N$-ミリストイル-Lーグルタミン酸ジナトリウム。 LGT : N-ラウロイル-L-グルタミン酸モノトリエタノールアミン塩, SLS : ラウリル硫酸ナトリウム, SLSa：ラウロイルザルコシンナトリウム

2) $\mathrm{S}:$ 溶解, G : ゲル状, SP : 一部溶解, $\mathrm{SH}:$ 〈もり

3）電導度法, 4) $60^{\circ} \mathrm{C}$ で测定 5) 色素法 6) ロスマイルス法,

7）液滴法 8）フェルトディスク法

N-アシルグルタミン 酸塩はジカルボン酸であるため, そのモノナトリウム塩の水溶液の $\mathrm{pH}$ は 5.0〜6.5の弱 酸性で, すぐれた起泡力, 表面張力低下能, 耐硬水性を 示した ${ }^{40)}$ 。また，L体と DL 体では溶解度をはじめ界面 活性能に差が認められた。とくに $N$-アシルグルタミン 酸ジトリエタノールアミン塩の $\mathrm{cmc}$ の対数 ( $\log \mathrm{cmc}$ ) とアシル基の炭素数 $(N)$ の関係は直線関係を示すが, 同じ炭素数のアシル基をもつ L 体と DL 体の $\mathrm{cmc}$ を比 較すると，L体の方が低い值を示した ${ }^{41)}$ 。そのほか，二

表 $2 N$-アシルアミノ酸ナトリウムの臨界ミセル濃度

$(\mathrm{mmol} / l)$

\begin{tabular}{l|r|r}
\hline \multicolumn{1}{c|}{ 陚 } & L-体 & DL-体 \\
\hline$N$-ラウロイルアラニンナトリウム & 9.7 & 11.8 \\
$N$-ラウロイルフェニルアラニンナトリウム & 2.8 & 3.0 \\
$N$-ラウロイルバリンナトリウム & 5.7 & 6.5 \\
$N$-ミリストイルバリンナトリウム & 2.6 & 3.0 \\
$N$-パルミトイルバリンナトリウム & 1.3 & 1.4 \\
\hline
\end{tabular}

* 色素法で測定 
表 $3 \quad N-$-アルアミノ酸塩の臨界ミセル濃度の 対数とアシル基の炭素数との関係

\begin{tabular}{|c|c|c|}
\hline 料 & $A$ & $B$ \\
\hline N-アシル-Lーバリソナトリウム & 2.77 & 0.167 \\
\hline N-アシル-DL-バリンナトリウム & 2.82 & 0.167 \\
\hline 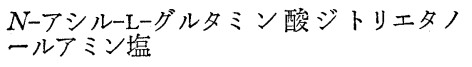 & 3.60 & 0.181 \\
\hline 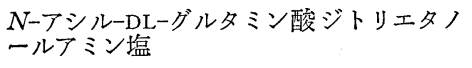 & 3.65 & 0.181 \\
\hline
\end{tabular}

ただし, log cmc (mmolar) $=A-B N$

$A ; B$ は定数, $N$ はアンル基の炭素数

三のN-アシルアミノ酸の場合にも同じ傾向があり ${ }^{42, * 2)}$, DL 体より L 体の cmc が小さく，したがって，L体の 方がミセルを作り易いと考えられる。従来, アミノ酸系 界面活性剤の光学異性体について, その界面活性能を比 較した例は少なく, 福田ら ${ }^{43)}$ がアラニンセチルエステル の単分子膜を形成せしめ FA 曲線を作成し, DL体と L 体との間に差があることを報告しているに過ぎない。し たがって，N-アシルアミノ酸塩の光 学活性とラセミ体 の界面活性能の差異についてはさらに詳しい検討が必要 である。

4. $N$-アシルアミノ酸塩の生分解性 界面活性剂 は種々の目的に使われているが，前述の如くその主な用 途は洗浄剤预よび表面処理剤である。界面活性剤が洗浄 などに使われた後は，排水に混入して廃棄されることに なる。したがって, 環境保全, 水質污濁防止の見地か ら，分解され易い界面活性剤が望まれる。界面活性剤の 生分解性については，1）第一次的な生分解，2）環境に 受け入れられる程度までの生分解，3）最終的な無機物 までの生分解の三つの段階にわけて考えられている ${ }^{44)}$ 。 従来からアニオン界面活性剤の生分解は残存界面活性剂 をメチレンブルー法などで定量して追跡する方法により 求められているが，この場合，必ずしも無機物まで分解 されたことを意味していない。最近の考え方では, 界面 活性剂は消費から廃棄を通じて各種水系の泡立ちといっ た外観上の問題のみならず，自然環境，生態系にいかな る影響を与えるかといら問題を考えなければならない。 したがって，生分解性については環境に受け入れられる 程度までの生分解, 望ましくは最終的な無機質までの生 分解が要求される ${ }^{45)}$ 。

このような観点から，N-アシルアミノ酸塩を界面活 性剂として用いるにはその生分解性について把握する必 要がある。すでに，N-アシルアミノ酸塩は酵素の作用 で分解されることが知られている。すなわち，N-ラウ

\footnotetext{
*2)「投稿中」吉田良之助, 竹原将博, 坂本一民, 油化学, アミノ酸系界 面活性剂 (第1 報) 光学活性およびラセミ $N$-アシルアミノ酸塩の臨 界ミセル濃度
}

ロイルーフェニルアラニンまたはーグリシンは Mycobacterium phlei によって水解され ${ }^{46)}$ ，また狭間らにより 動物の腎臟から $N$-アシルアミノ酸を分解する酵素が精 製されている ${ }^{47)}$ 。さらに, ラットの肝臟から分離した酵: 素の作用により，フェニルアラニンとパルミチン酸また はモノオレインから，N-パルミトイルーまたは $N$-オレ オイルーフェニルアラニンが合成されることを認めた ${ }^{48)}$ 。 最近, 鈴木らは Lactobacillus 属の菌体抽出物により, $N$-アシルアミノ酸を特異的に加水分解する方法を見出 した ${ }^{49)}$ このような事実から $N$-アシルアミノ酸を合成. したり, 分解したりする酵素が自然界に存在するものと 考えられ，したがって，N-アシルアミノ酸は自然界に おいて容易に生分解されるものと考えられる。

$N$-アシルグルタミン酸の生分解性については上村ら が詳細に検討した ${ }^{50)}$ 。すなわち, 活性污泥を用いる JIS 法に準じて, LASや, ラウリル硫酸ナトリウム (SLS) と 比較した。N-アシルーLーグルタミン酸ナトリウム (AGS) は LAS に比し容易に分解され, SLS と同じ程度であっ た。しかし，この方法では人為的な活性污泥による分解 であり, 自然状態での分解性を示していない。自然状態 での分解性を調らべる目的で, 河川の表面水中に存在す る微生物を用いて, 静置状態で酸素の消費量から, その 分解性が検討された。その結果も AGS は高級アルコー ル系の SLS と同じ程度によく分解された。その結果を 図 1 に示した。また他の $N$-アシルアミノ酸についても 生分解され易いという報告がある ${ }^{50)}$ 。

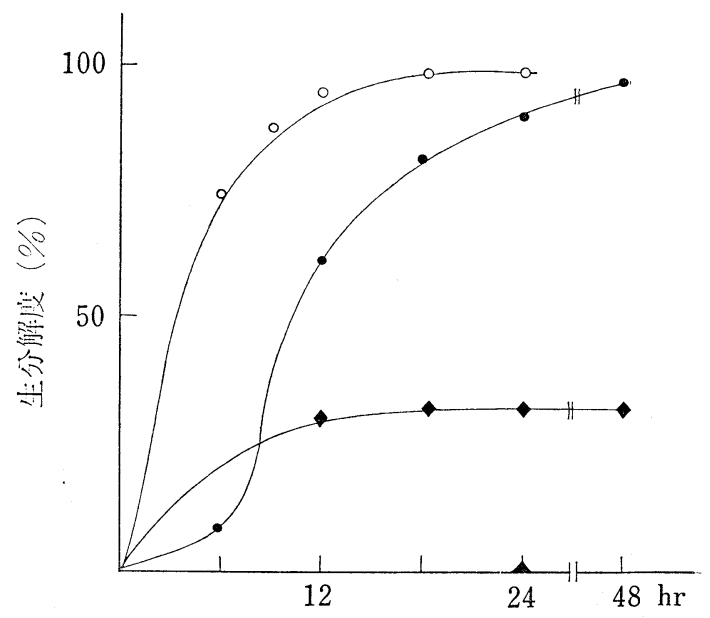

図 1 静置状態で微生物による界面活性剤の生分解性

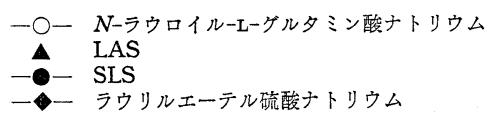

5. 安全性 N-アシルーLーグルタミン酸塩を香粧品 
用界面活性剂として利用する目的で，その生体への作用 が調べられた。新らしい界面活性剤を化粧品, トイレタ リーに応用するには，その毒性，皮膚または粘膜に対す る作用が, 従来から使用されているものに比して小さい ことが望ましい。

一般に界面活性剤はタンパク質に付着または吸着し易 く,タンパク質を変性させることが知られている51)。ま た, 臨床的にも家婦湿疹をはじめ種々の皮膚炎の原因と なる可能性があるといわれている。

タンパク質分子内の $\mathrm{SH}$ 基の露出度を指標として, AGS, SLS を主剤とする固型洗版および石けんのタンパ ク質変性度が比較された ${ }^{51)}$ 。界面活性剂の濃度が高くな ると, タンパク質の変性度が大きくなるが, AGS は SLS または石けんに比して変性度が小さいと報告され た。また，ヒ卜皮膚由来の培養細胞株 (XX-male) 飞対 する細胞障害性も比較され，AGS は最も障害が少な く22，したがって皮膚に対して温和な界面活性剤である と報告された。

N-アシルーLーグルタミン酸塩の急性経口毒性, 皮膚ま たは眼粘膜に対する一次刺激性を動物を用いて調べたと ころ，従来から用いられている SLS などに比し，はる かに刺激性が少なく，さらに光毒性，アレルギー性のな いことが確かめられた ${ }^{15,53) 。 ~}$

つぎに人皮膚に対するパッチテスト，使用試験により AGS が固型洗鼡として安全に使用できることを認め, さらに, 皮膚疾患患者に対する臨床試験が実施され, こ れらの人々にも使用できることが認められた ${ }^{15,54}$ 。

\section{6. $N$-アシルアミノ酸塩の用途 Hentrichらは $N$ -} アシルアミノ酸塩が界面活性郕として用い得るという報 告をし，その後もいくつかの特許が出された。しかし， 従来注令酸が比較的高価であったため, 実用化され たものは，N-アシルザルコシン塩が八ミガキに添加さ れたり ${ }^{55,56)}, N$-アシル-N-メチルー- - -アラニン塩がシャ ンプーの添加剤に用いられた ${ }^{57]}$ ほか，タンパク質の加水 分解により得られたアミノ酸をたはぺプチドのアシル化 物が用いられたに過ぎなかった。しかし，アミノ酸の中 で最も多量に生産され，比較的安価な L-グルタミン酸 を原料とする $N$-アシルーレーグルタミン酸の新らしい製 造法が確立され，これをきっかけとして，AGS を水と 混練して固型化する新らしい固型洗㓮 (Syndet Bar) が 開発され ${ }^{58)}$ ＊3)，さらに種々の香粧品用界面活性剤とし

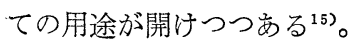

*3) 「投稿中」吉田良之助, 薄羽恭謙, 吉村一平, 渋江昭夫, $J . A m$. Oil. Chemists Soc. Surface Active $N$-Acylglutamate V. Application of $\mathrm{N}$-Acylglutamate to Detergent Bars.
$N$-アシルアミノ酸塩の抗 菌性についても古くから検 討されており，たとえば，解田らは $N$-ラウロイルフェ ニルアラニンが Staphylococci に対し抗菌性を有する ことを確認した ${ }^{59}$ 。Fosdick らは虫歯予防剂として多く の化合物を検索し， $N$-ラウロイルザルコシン塩がすぐれ ていることを認めた ${ }^{55}$ 。さらに，他の $N$-アシルアミノ 酸塩もこ礼らの目的に用い得るといら特許がある 65)。

N-アシルアミノ酸がウイルス性疾患の治療薬として

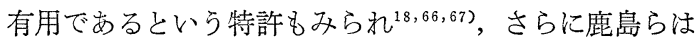
とくに $N$-アシル-L-グルタミン酸がグルタミン酸発酵 に拉いて，バクテリオファージの感染を阻止する作用が 強いことを見出した ${ }^{68)}$ 。また，N-アシルアミノ酸が稲 のいもち病，キュウリのうどんこ病菌など植物性病原菌 の防除する效果があることを見里らが見出した ${ }^{69 \sim 71) 。 ~}$ また，N-ラウロイルバリンは土培中の微生物により容 易に分解され，残留毒性の心配がないことが確認されて いる72)。

工業用分野で法, 繊維の柔軟性を保つ洗浄剂 $\left.{ }^{7}, 8\right), N-$ アシルザルコシン塩を中心とした潤滑油への添加，防錆 剂としての特許がある ${ }^{73 \sim 78}$ 。その他, 工業用乳化剂, プ ラスチック添加剤としての応用が検討されている78,79)。 さらに，N-アシルザルコシン塩を浮選片として用いる 例も㐫る ${ }^{80)}$ 。また，N-アシルグルタミン酸塩は重金属 イオンと難溶性の塩を作るため，金属捕捉剤，イオン浮 選剤としての可能性もある ${ }^{81 ~ 83) 。 ~}$

7. N-アシルアミノ酸の誘導体Ｎ-アシルアミノ 酸をエステル化した $N$-アシルアミノ酸エステルの中に 種々の特性をもつ物 質がある。たとえば， $N$-ラウロイ ルーLーアルギニンエチルエステル塩は一種のカチオン系 界面活性剤であるが，毒性が少なく，しかも抗菌性にす ぐれている ${ }^{84,85) 。 ま た, ~} N^{\delta, \delta}$-ジメチル- $N^{\alpha}-$ ラウロイル オルニチンエステルなぞも同様の効果がある ${ }^{86)}$ 。ペプチ ド抗生物質であるポリミキシンのモデルとして研究され たパルミトイルーLーリジルーLーリジンメチルエステル塩 酸塩はリジンのジペプチドのアシル化物であるが広範囲

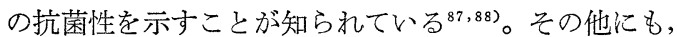
グラム陰性菌に対し抗菌性を示寸環状デカペプチドのコ リスチンを簡単化したアシルペプチドを作り，その抗菌 性を調べ，抗菌性の発現には塩基性アミノ酸を含み， $\alpha$ 位がアシル化され， $\omega$ 位に遊離のアミノ基をもつ必要が あるという報告もある898。

一方，N-ラウロイル-L-グルタミン酸と高級アルコー ルより得られるエステルは油に対して相溶性のある油状 物またはワックス状のものである。また，ポリオキシエ 
チレン (10 mol 以下) 高級アルコールエーテルとのエ ステルは弱、界面活性能を有する油溶性物質であり，整 髪料などに用いられる ${ }^{90,91) 。 ~}$

\section{III. アミノ酸エステル}

アミノ酸エステルの研究はタンパク質分解物からアミ ノ酸を分離する方法の一つとして進められた。すなわ ち, タンパク質の分解により得られたアミノ酸混合物を 酸触媒の存在下に低級アルコールと反応させ，アミノ酸 エステル塩を合成し，アルカリ処理により遊離のエステ ルとし，これを減圧下に分留して，アミノ酸を分離し た。アミノ酸の高級アルコールエステル塩に関する報告 は比較的少なく, 1941 年, Harris らはグリシンおよび アラニンのラウリルエステル塩酸塩を合成し，それらが

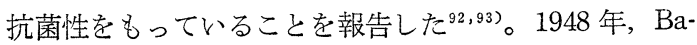
niel らはグリシン，アラニンなどの高級アルコールエス テルを めーハロゲン酸高級アルコールエステルとヘキサ メチレンテトラミンから合成し，単分子膜を作らしめて 重合を試み ${ }^{94)}$ ，Garber らはリジンオクチルエステルを イソシアナートに誘導してポリウレタンを得ている ${ }^{95) 。}$ また, Vries らはグルタミン酸ーrーラウリルエステルを $N$-カルボン酸無水物を経て重合させ ${ }^{96,97)}$, 潤滑油など の添加剤, 油脂の乳化剂として検討している。猿野らは このグルタミン酸エステルの重合物が食品, 化粧品用界 面活性剤に用いられると述べている ${ }^{98)}$ 。

1953 年，野ロらはグリシンおよびアラニンのラウリ ルエステルを合成し, その塩酸塩水溶液が界面活性能を 有し，逆性石けんとして用い得ると報告した ${ }^{999}$ 。

一般にこれらのアミノ酸エステルはアミノ酸と高級ア ルコールを溶媒中, 塩化水素あるいは $p$-トルエンスル ホン酸などの酸触媒を用いて加熱還流し, 生成した水を 共沸脱水する方法で合成される ${ }^{99,100)}$ 。

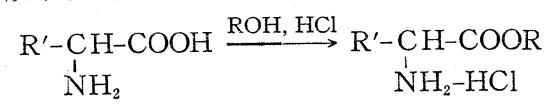

\section{IV. $N$-アルキルアミノ酸}

アミノ酸の N-アルキル誘導体に属する界面活性剂と しては, グリシン型, $\beta$ アラニン型, アルキルベタイ ン型などが知られており，アルキルアミンとモノクロロ 酢酸などとの反応により合成されたものが多い。

アミノ酸から誘導された $N$-アルキルアミノ酸型の両 性界面活性剤は，1,2-エポキシアルカンとアミノ酸の反 応により合成された ${ }^{101 \sim 103)}$ 。川島らはグルタミン酸と 1 , 2-エポキシアルカンをアルカリの存在下, 含水エタノー ル中で反応させ， $N$-(2-ヒドロキシアルキル) グルタミ

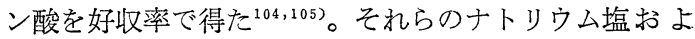
び酸化エチレン付加物の界面活性能を報告している ${ }^{106)}$ 。

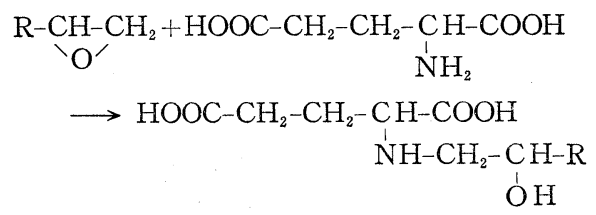

\section{V.おわりに}

アミノ酸および脂肪酸を原料とする界面活性剤，すな わち $N$-アシルアミノ酸塩について述べ,さらにアミノ 酸より誘導される界面活性剤にも触れた。N-アシルア ミノ酸は酵素の作用で合成されたり, 分解されたりする のみならず，生体中に存在するものもある。すなわち， Cray fish（ザリガニ）または Lobster から N-アシル タウリンおよび $N$-アシルジペプチド（タウリンとシス ティン酸のペプチド) が分離された ${ }^{107)}$ このように, $N$-アシルアミノ酸は天然物中の存在が確認されている ほか，前述のように毒性が低く，生分解性の高い界面活 性剤であるから，現代の要請にかなったものと考えら れ，さらに新らしい利用法が開発され，今後発展するも のと期待される。

(昭和 50 年 2 月 27 日受理)

\section{文献}

1）日本油化学協会主催第 5 回洗浄に関するシンポジ ウ厶 1973 年 10 月 $3 \sim 4$ 日

2）官報第 13902 号，厚生省告示第 98 号（昭和 48 年 4 月 28 日)

3) S. Bondi, Z. Biochem. 17 543, 553 (1909)

4) E. Abderhalden, C. Funk, Z. Physiol. Chem. 6561 (1910)

5) G. Izar, Z. Biochem. 40390 (1912)

6) P. Karrer, E. Miyamichi, H.C. Storm, R. Widmer, Helv. Chim. Acta 8205 (1925)

7) W. Hentrich, H. Keppler, K. Hintzmann, Ger. P 546,942 (1930)

8) W. Hentrich, H. Keppler, K. Hintzmann, Ger. P 635, 522 (1936); BP 459, 039 (1936)

9) H. Staudinger, H.V. Becker, Ber. 70889 (1937)

10) M. Naudet, Bull. Soc. Chim. France 358

11）局敏郎，生化学 3567 (1963)

12）須山正，豊田猛，金尾清造，薬誌 86967 (1966)

13) P. Heitmann, Eur. J. Biochem. 3346 (1968)

14) P. Heitmann, Eur. J. Biochem. 5305 (1968)

15）吉田良之助，有合化 32582 (1974)

16) E.B. Kester, USP 2, 463, 779 (1949)

17) E. Jungermann, J.F. Gerecht, I.J. Krems, J. Amer. Chem. Soc. 78172 (1956)

18）上田武雄, 加藤貞武, 豊島滋, 日特公 昭31-9568, (1956) 
19) B. Weiss, J. Org. Chem. 241367 (1959)

20) M. Takehara, I. Yoshimura, K. Takizawa, R. Yoshida, J. Am. Oil Chemists' Soc. 49157 (1972)

21) J.R. Vaughan, J.A. Fichler, J. Amer. Chem. Soc. 762474 (1954)

22) M, Fieser, L.F. Fieser, E. Toromanoff, Y. Hirata, H. Heymann, M. Tefft, S. Bhattacharya, J. Amer. Chem. Soc. 782825 (1956)

23）妹尾三郎, 山下武, 野嶋美登里, 矢野信光, 日特 公 昭 40-14004 (1965)

24）山村雄一, 永松淳雄, 日特公 昭 42-11925 (1967)

25) G. Schroeder, W. Gaenzler, J. Babuliak, P. Uddrich, Ger. Offen 2,004,009 (1971)

26）滝沢宏一，吉田良之助，日特開昭 49-1513 (1974)

27）吉田良之助, 吉村一平, 前田事紀, 竹原将博, 滝 沢宏一，日特公 昭 48-35058 (1973)

28) J.J. Singer, $F P$ 1,465,959 (1967); BP 1,087, 696

29）上田武雄, 加藤貞武, 豊島滋, 日特公 昭 32-8410 (1957)

30）斎藤千春，土岐克之，鈴木義雄，小林晃，日特公 昭 40-9131 (1965)

31）奥村健太郎，吉川浩，井上一三，日特公 昭 38461 (1973)

32）林正樹，今西きぬ子，日特公 昭 43-12330（1968）

33）白井忠, 成田敏郎, 山口剛一, 荒井慶一, 蔵重修 二, 有合化 3068,76 (1972)

34）若松八郎，菟田順子，山上信之，日特公 昭 4817259 (1973)

35) H. Wakamatsu, J. Uda, N. Yamakami, Chem. Commun. 19701540

36) E.S. Rothman, J. Am. Oil Chemists' Soc. 45 189 (1968)

37) E.S. Rothman, S. Serota, J. Am. Oil Chemists' Soc. 48373 (1971)

38) R.G. Bistline, Jr., E.S. Rothman, S. Serota, A.J. Stirton, A.N. Wrigley, J. Am. Oil. Chemists'Soc. 48657 (1971)

39）大木建司, 常盤文克, 油化学 19897 (1970)

40) M. Takehara, H. Moriyuki, I. Yoshimura, R. Yoshida, J. Am. Oil. Chemists' Soc. 49143 (1972); M. Takehara, H. Moriyuki, A. Arakawa, I. Yoshimura, R. Yoshida, J. Am. Oil Chemists' Soc. 50227 (1973)

41) M. Takehara, I. Yoshimura, R. Yoshida, J. Am. Oil Chemists' Soc. 51419 (1974)

42）吉田良之助, 竹原将博, 坂本一民, 第13回油化学 研究発表会講演要旨集 p. 36 (1974)

43）天海孝，中原弘雄，柴崎芳夫，福田清成，第26回 コロイドおよび界面化学討論会講演要旨集 p.54 (1973)

44) 浅原照三，化学総説 2137 (1973)

45) 大場健吉, 油化学 23665 (1974)

46）象田幸雄，豊浦悦子，薬誌 72402 (1952)
47) H. Hazama, Kyushu J. Med. Sci. 12135 (1961)

48) T. Fukui, B. Axelrod, J. Biol. Chem, 236811 (1961)

49）鈴木直雄，下田善也，日特公 昭 48-25514 (1973)

50）上村晃，日本農芸化学会 昭和 48 年度関東支部大 会講演要旨集 p. 3 (1973)

51）二宮冬彦，木下啓，小倉良平，皮膚科紀要 6897 (1973)

52）小西宏明，井上佳子，渥美隆正，安藤寛治，小林 正久，第73回日本皮膚科学会講演要旨集 (1974)

53）中山秀夫，原明弘，吉田良之助，日本皮膚科学会 誌 82565 (1972)

54) H. Nakayama, H. Hanaoka, A. Ohckiro, "Allergen Controlled System” p. 4., p. 29 (1974); Kanehara Shuppan Co., Ltd.

55) L.S. Fosdick, J.C. Calandra, R.Q. Blackwell, J.H. Burrill, J. Dental Res. 32486 (1953)

56) W.J. King, USP 2,689,170 (1954)

57）石井睦雄, 滝沢秀光, 薄羽恭謙, 石川一男, 森本 圭佑，秋葉一，油化学 17616 (1968)

58）吉田良之助, 竹原将博, 秋葉一, 薄羽恭謙, 日特 公 昭 48-11805 (1973)

59）亀田幸雄，豊浦悦子，大島正一，辻美和子，入江 千代子，薬誌 673 (1947)；68 143 (1948)

60) 清水晃, 成井喜久子, 桐村二郎, 日特公 昭 4614357 (1971)

61）清水晃, 成井喜久子, 桐村二郎, 日特公 昭 4524480 (1970)

62) J.V. Morelle, BP 1,153,408 (1969)

63) J. V. Morelle, USP 3,624,114 (1971)

64) J.V. Morelle, FP 2,154,334 (1973)

65）渋江昭夫, 石川一男, 石井睦雄, 日特公 昭 4620720 (1971)

66）上田武雄，加藤貞武，豊島滋，日特公 昭 33-1866 (1958)

67）上田武雄, 加藤貞武, 豊島滋, 日特公 昭 32-2247 (1957)

68）鹿島信一，山中茂，光木浩司，広瀬義夫，日本農 芸化学会昭和 49 年度大会講演要旨集 p. 433 (1974)

69）見里朝正，黄耿堂，本間保男，金尾清造，豊田 猛，須山正，日特開 昭 47-16639 (1972)

70）見里朝正，日特開 昭48-49922（1973）

71）本間保男, 志田俊郎, 見里朝正, 日本植物病理学 会報 39 (2) 90 (1973)

72) T. Shida, Y. Homma, T. Misato, Agr. Biol. Chem. 37 (5) 1027 (1973)

73) J.D. Spivack, W.M. Gardner, Am. Chem. Soc., Div. Petroleum Chem. General Papers, No. 33, 365 (1955); C.A. 50 13419c

74) J.L. Murray, R.A. Westlund, USP 3,046,225 (1962)

75) G.W. Eckert, USP 3,109,719 (1963)

76) R. Davis, 日特公昭 40-13493 (1965)

77） Mobil Oil Co., 日特公 昭 44-17498 (1969) 
78) H. Witte, W. Seeglinger, H.D. Hesse, W. Kriesten, Ger. Offen 2,017,397 (1971)

79) M.F. Bruno, Belg. P 636,936 (1964)

80) P. Young, Z. Erzbergbau u. Metallhüttenw. 14 (4) 184 (1961)

81）稲塚新一, 竹原将博, 吉田良之助, 日特公 昭 493755, 昭 49-7319 (1974)

82）稲塚新一, 竹原将博, 吉田良之助, 日本化学 会 第 31 秋季年会講演要旨集 p. 610 (1974)

83）伊藤公吉, 加藤義重, 鈴木正臣, 鈴木恵子, 日本 化学会第 26 春季年会講演要旨集 p. 216 (1972)

84）竹原将博, 斎藤忠臣, 赤松晄, 吉田良之助, 日特 公昭 47-313 (1972)

85) R. Yoshida,T. Saito, M. Takehara, F. Yoshinaga, $B P$ 1,352,420 (1974)

86）赤松晄, 竹原将博, 玉川吉雄, 吉田良之助, 日特 公昭 43-64129 (1968)

87) K. Vogler, P. Lanz, P. Quitt, R.O. Studer, W. Lergier, E. Böhni, B. Fust, Helv. Chim. Acta 47526 (1964)

88） K. Vogler, 日特公 昭 42-27642 (1967)

89）栗原藤三郎, 武田秀雄, 伊藤秀雄, 薬誌 941004 (1974)

90）市川智通，日本化粧品技術 者連合会会誌 97 (1974)

91) T. Ichikawa, S. Fukami, Ger. Offen 2,353,088 (1974)

92) B.R. Harris. USP 2,317,378 (1941)
93) A.R. Epstein, B.R. Harris, USP 2,229,174 (1941)

94) A. Baniel, M. Frankel, I. Friedrich, J. Org. Chem. 13791 (1948)

95) J.D. Garbel, R.A. Gasser, D. Wasserman, Neth. Appln. 6,515,246 (1966)

96) L. Vries, J.R. Thomas, USP. 3,119,794 (1964)

97) Merck \& Co., Inc., Neth. Appln. 6,500,089 (1965)

98）猿野琳太郎，石田賢吾，日特公昭 43-21861 (1968)

99）野口順蔵, 広野達夫, 米谷清正, 谷久也, 結城平 明, 吉田道雄, 日化 74894 (1953)

100）荻原通弘，日特公 昭 46-41286 (1971)

101) E. Ulsperger, Fette Seifen Anstrichmittel. 68 964 (1966)

102) A. Cahn, T.J. Kaniecki, Belg. P 618,901 (1962)

103） アトランティック，リッチフィールドカンパニー 日特公 昭 46-19958 (1971)

104） 丸茂秀雄，日特開 昭 48-72118 (1973)

105）川島正毅, 二宮守男, 高井誠, 日本化学会第30春 季年会講演要旨集 2 M. 13 (1974)

106）川島正毅，高田満信，石川宣次，二宮守男，高井 誠, 日本化学会第 30 春季年会講演要旨集 2 M. 14 (1974)

107) D.A. Holwerda, H.J. Vonk, Comp. Biochem. Physiol. 1973 Vol. 45B 51

\section{次号予 定}

総 説

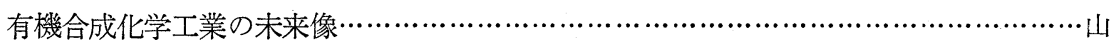

これからの有機合成化学工業原料について…………..............................平川芳＼cjkstart彦

報 文

$\mathrm{N}, \mathrm{N}^{\prime}$-二置換チオ尿素と 2-クロロ-4, 6-ジメチルピリミジン，2，4-ジクロロピリ

ミジシまたは $\mathrm{N}$ ーフェニルベンズイミドイルクロリドからのカルボジイミドの合成……古＼cjkstart元＼cjkstart貞＼cjkstart好

資 料

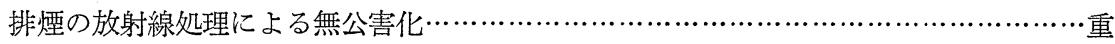

アルドール縮合とその工業技術…………

松友道

\section{技術発達史}

ポリエステル原料一テレフタル酸，ジメチルテレフタレート製造技術の変遷…………市 川 弥 太 郎

\section{化合物合成法}

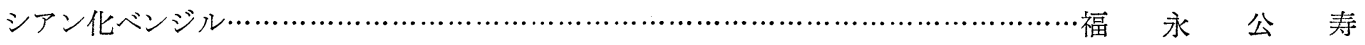

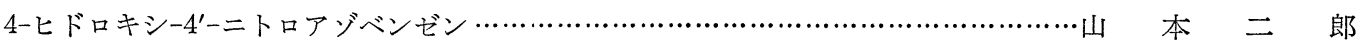

その他 